\title{
Targeted Release in the COVID-19 Correctional Crisis: Using the RNR Model to Save Lives
}

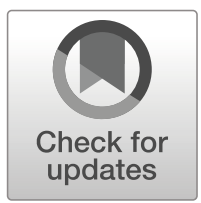

\author{
Brenda Vose $^{1} \cdot$ Francis T. Cullen ${ }^{2} \cdot$ Heejin Lee $^{2}$
}

Received: 11 May 2020 / Accepted: 1 June 2020 /

Published online: 19 June 2020

(C) Southern Criminal Justice Association 2020

\begin{abstract}
While the COVID-19 pandemic has dramatically affected the lives of people around the world, select populations (e.g., elderly, immune-compromised, and incarcerated individuals) are among the most likely to contract the virus and among the least likely to overcome the illness and regain full health. This paper focuses on the incarcerated individuals and how the coronavirus has added a new and unprecedented threat to correctional facilities that are already overcrowded and ill-equipped to identify and address the medical needs of the inmate population. The risk-need-responsivity model (RNR) should be used to make empirically-informed decisions about the targeted release. The identification and release of inmates who pose the least threat to society will help alleviate some of the burdens associated with prison crowding. Specifically, with fewer inmates, correctional facilities can comply with social distancing guidelines, introduce enhanced cleaning measures, and make necessary institutional adjustments. In so doing they will limit the transmission of COVI-19 within correctional institutions, ensure the safety of staff and their charges, and enable prisons and jails to better accommodate the needs of the inmate population.
\end{abstract}

Keywords COVID-19 $\cdot$ Coronavirus $\cdot$ Downsizing $\cdot$ Prisoner health $\cdot$ RNR model

Brenda Vose

brenda.vose@unf.edu

Francis T. Cullen

cullenft@ucmail.uc.edu

Heejin Lee

lee3hi@ucmail.uc.edu

1 Department of Criminology and Criminal Justice, University of North Florida, Jacksonville, FL 32224, USA

2 School of Criminal Justice, PO Box 210389, University of Cincinnati, Cincinnati, OH 45226, USA 


\section{Introduction}

The United States remains in the grips of the Coronavirus Disease 2019 (COVID-19) pandemic. The nation's first report of a coronavirus infection was on January 21, 2020, and the first reported death occurred on February 29. By the end of March, the toll had risen to 123,653 cases and 2135 deaths; by the end of April, these figures had risen exponentially to more than 1 million cases and 65,000 deaths; and by the end of May, the statistics surpassed 1.7 million cases and 100,000 deaths ("Coronavirus in the U.S.," 2020a, b; Wilson, 2020). In a context of no national policy for suppressing the rate of infection and for mass testing and of states implementing a polyglot of social distancing policies, little reason currently exists that the virus will be contained effectively and that its toll in illness and lives lost will be minimized. Like a car odometer on a cross-country trip, these tragic numbers will roll forward intractably. Estimates place lives lost to the coronavirus at 134,000 by early August; other predicted counts are higher (Faust and del Rio, 2020; Levenson, Holcombe, Azad, and Almasy, 2020). Hopes of a vaccine or a cure are mounting, but we have no medical Nostradamus to tell us when relief will arrive. The reality is that effective vaccines can take years to perfect (Thompson, 2020).

Although the bars and walls of the nation's correctional institutions are effective in keeping offenders inside, they are incapable of keeping out diseases that threaten inmate and staff health. The effects of prisons on inmate health are complicated. Because of general racial and class inequality in health care delivery and offenders' poor health practices prior to incarceration, inmates' prevalence rates for some chronic diseases and for mortality are lower than for the U.S. population (Potter and Rosky, 2014). For infectious diseases (e.g., hepatitis $\mathrm{C}$ infection), however, the opposite is the case (Potter and Rosky, 2014) — which of course has dire implications for the coronavirus. The key point, observe Potter and Rosky (2014, p. 167), is that "healthy prisons reflect healthy societies." When this is not the case, "sick prisons" are the result.

In this context, the importation of COVID-19 into prisons and jails has been striking and consequential. Reports of inmate and staff infections and deaths emerged in midMarch. By May 2, the toll had risen to 26,300 cases and 266 deaths behind bars. This spread of the virus should not be surprising. In the 1918 outbreak of the Spanish influenza, California's San Quentin Prison endured three separate epidemics. In the first and most serious wave, a sick inmate transferred from the Los Angeles county jail triggered an infection that spread to about half the 1900 prisoners (Stanley, 1919; see also Hawks, Woolhandler, and McCormick, 2020). A century later, contemporary prisons and jails differ little, remaining incubators of infection and limited in their ability to social distance their inhabitants. Writing in the JAMA Internal Medicine, Hawks et al. (2020) recognize the impending health crisis. They assert that "the only way to avoid the imminent outbreak is...to drastically reduce the populations of jails and prisons," including "reducing unnecessary jail admissions and expediting prison release."

Fortunately, Americans are likely to favor this policy. In recent years, punitive sentiments have declined (Enns, 2016; Pickett, 2019), whereas studies in diverse states have shown high public support for offender reform and downsizing prison populations (Sundt, Cullen, Thielo, and Jonson, 2015; Thielo, Cullen, Cohen, and Chouhy, 2016. Not surprisingly, a mid-March 2020 poll of 1310 registered voters found that $63 \%$ 
supported measures to "reduce the coronavirus risk in prison" by releasing pre-trial detainees and elderly people (Franklin and Reis, 2020). This finding is significant, but it does not address other types of offenders or inform respondents what steps would be taken to ensure their continued safety. That said, the American public is likely open to downsizing institutional populations to save offenders from infections. Inmates' punishment cannot legitimately involve COVID-19 illness or death.

The key issue, however, is how to reduce the incarcerated population. The purpose of this essay is to argue that one tool to use in offenders' release from prison or diversion from jails is the risk-need-responsivity model, commonly known as the RNR model. As a prelude to making this case, we explore why correctional institutions are dangerous places in the COVID-19 epidemic. We first discuss the nature of total institutions and then argue that, despite their unique features, prisons and jails are similar to these institutions in vulnerability to the pandemic. We then examine efforts at the federal, state, and local levels to implement downsizing policies.

\section{COVID-19 and Total Institutions}

Prisons have a unique function - holding those convicted of a crime in custody - but they are not fully unique places. Other social environments similarly circumscribe the lives of their residents. Erving Goffman (1961) used the term "total institutions" to describe places where three core features of life that are usually undertaken in separate social domains - sleep, play, and work - occur in a single location. "A total institution," Goffman (1961, p. xiii) observed, "may be defined as a place of residence and work where a large number of like-situated individuals, cut off from the wider society for an appreciable period of time, together lead an enclosed, formally administered round of life." Although "prisons serve as a clear example," he noted that other types existed, including homes that are for the aged and merchant ships. A key characteristic is that "each phase of the member's daily activity is carried on in the immediate company of a large batch of others" (Goffman, 1961, p. 6, emphasis added).

The coronavirus has touched virtually every community in the United States, but it reserved among its most insidious effects for total institutions. A toxic brew of two ingredients ensured that the toll in illness and death would be disquieting. One ingredient, noted just above, was that the routine activities in such institutions ensure that every individual will be in "the immediate company" of a "large batch of others." Close-proximity interpersonal contact is thus inevitable and continuous. The second ingredient is the nature of COVID-19. As a novel virus, humans have no immunity to transmission, which occurs mainly through large droplets (del Rio and Malani, 2020). Those with the regular flu infect, on average, 1.3 others (Sheikh, Watkins, Wu, and Gröndahl, 2020). By contrast, it is estimated that hosts of the coronavirus in the general population infect two to three individuals, which explains why the rate of infection grows exponentially (del Rio and Malani, 2020). Further, hosts can infect others while being asymptomatic. The incubation period for the virus ranges "from 1 to 14 days, with a median of 5 to 6 days" (del Rio and Malani, 2020, p. 1339).

Once a resident or staff was infected, the very nature of total institutions ensured the near universal infection of the population. Close and continued daily contact ensures that this highly communicable disease would spread rapidly, with hosts infecting others even before they knew they were ill and medically dangerous. Life Care Center, a 
nursing home in Kirkland, WA was at the epicenter of the emergence of COVID-19 in the United States. Two residents perished from the disease on February 26, 2020. A month later, two thirds of the population tested positive and 35 were dead. Forty-seven workers became sick, some of whom transmitted the infection to other long-term facilities where they also worked (Healy and Kovaleski, 2020). The tragedy at the Life Care Center was a harbinger of things to come. Nursing homes across the nation suffered dozens of deaths. By early May, there were reports of 118,000 cases of resident and staff infections as well as a death count of more than 19,000 ("Coronavirus in the U.S.," 2020a; Nadolny and Kwiatkowski, 2020). By the month's end, the count exceeded 197,000 cases and 37,000 deaths ("Coronavirus in the U.S.," 2020b). Families now visit patients by staring through windows while conversing on cell phones.

Events on the Diamond Princess showed the threat to passengers of cruise shipsagain, a closed environment with close interactions (Mallapaty, 2020). In early February, an outbreak of cases led to the ship being quarantined while docked in Yokohama, Japan. Of 3711 passengers and crew, 712 people-nearly 20\% of the ship's population - tested positive for the coronavirus. Eventually, 381 manifested symptoms, 37 were placed in intensive care, and 9 died (Moriarty et al., 2020). Since that time, 25 other cruise ships have reported coronavirus cases, most notably the Grand Princess, which suffered 103 infections and three deaths and was quarantined for a week off San Francisco Bay (Mallapaty, 2020; Webeck, 2020). Navy vessels encountered similar problems, most notably the USS Theodore Roosevelt. The plight of the carrier grabbed national headlines when its captain, Brett Crozier, was relieved of his command for writing a letter to his superiors, leaked to the press, detailing the risk COVID-19 posed to the health of his 4500 -member crew. Crozier's concerns proved prescient, as the virus took one sailor's life and infected more than 1100 others, including the captain himself (Seligman, 2020).

Meat packing plants provide one more example. Although not encompassing all aspects of employees' lives as do prototypical total institutions, these facilities keep their charges in a confined space and in the immediate company of batches of others for the entire workday. Immigrants, including refugees from around the world, comprise a large slice of the vulnerable workforce in many plants (Dickerson and Jordan, 2020). As Dyal et al. (2020) note, "the meat and poultry processing industry, an essential component of the U.S. food infrastructure, employs 500,000 persons, many of whom work in close proximity to other workers." The "congregate" work environment makes preventative social distancing measures (spaced $6 \mathrm{ft}$ apart) difficult. Perhaps not surprisingly, the health statistics are troubling. By the end of April 2020, aggregated data from 115 plants reported to the Centers for Disease Control and Prevention (CDC) revealed 4913 cases of infection (about 3\% of workers) and 20 deaths (Dyal et al., 2020).

\section{The Correctional Health Crisis}

The discussion thus far sets the context for making two interrelated points. First, all total institutions are vulnerable to the spread of this novel virus. Second, the presence and devastating effects of COVID-19 in the nation's correctional facilities are not due to some inherent pathology of their population but mostly due to their status as a total 
institution. In prisons and jails, the inhabitants — offenders and staff — sleep, work, and play in the immediate presence of others. The supervised daily routine activities ensure congregate living - often sleeping together, working together, eating together, socializing together. By design, cell and living space is at a minimum - a situation made more cramped by institutional overcrowding. As Toussaint (2020) warned, "prisons are just as much of a hotbed for transmission as cruise ships."

This harsh reality was manifest in mid-March 2020 when Rikers Island, the jail for New York City, became, in the words of the facility's top doctor, a "public health disaster unfolding before our eyes" (Bryant, 2020). Within two weeks, Rikers and other city jails reported infections in 180 prisoners and 141 staff members (Bryant, 2020). Three weeks into April, the toll infected cases at Rikers had risen to at least 365 inmates (including two deaths), 783 correctional staff, and 130 medical workers (Brown, 2020). For offenders housed in dormitories, beds were placed within three feet of one another. To "social distance," residents were instructed to sleep head to feet (Brown, 2020).

The situation in New York was not unique. At the Trousdale Turner Correctional Center - a private prison in Tennessee-COVID-19 infections proved to be widespread. Of 2725 inmates and staff tested, 1349 or almost half were positive for the virus (Tennessean Staff, 2020). Similarly, at Ohio's Marion Correctional Institution that houses 2500 offenders, $80 \%$ of the inmate population tested positive for the coronavirus as well as over 160 staff members and correctional officers. About 66 cases in the community were linked to the prison pandemic (Volpenhein, 2020a). Protests arose outside the facility, with citizens carrying signs saying that incarceration is "not a death sentence" (Volpenhein, 2020b). Indeed, as the toll in illness and death mounted, lawsuits alleging "cruel and unusual punishment" were filed across the United States (see, e.g., Hammel, 2020; Samilton, 2020; see also Matz, 2020). As of May 27, 2020, the New York Times "counted more than 47,000 coronavirus infections and 485 deaths in inmates and staff at state prisons, federal prisons and local jails" ("Coronavirus in the U.S.," 2020b).

\section{The Need to Release Prisoners}

In the Spanish flu outbreak in 1918, officials at California State Prison San Quentin confronted the stubborn reality that curbing its spread through the institution was a daunting task. Three waves of the epidemic hit the prison, which taught them that "the disease is transmitted by close contact" (Stanley, 1919, p. 1005). Inmates were given masks, but "the men...soon discarded them for the most part" (Stanley, 1919, p. 999). Congregate viewing of picture shows and other "assemblages" were stopped. New inmates were quarantined before being allowed to enter the general population as were inmates displaying influenza symptoms. The prisoners were warned "against close contact and congregating in inclosed places" (Stanley, 1919, p. 1005). But in the end, officials could do only so much to protect their charges. As a total institution, San Quentin was an incubator of the disease.

With the advent of COVID-19 pandemic, contemporary prison officials have learned the same lesson that once the virus is imported into a facility, halting its spread across inmates and staff is impossible. Certainly, as was the case with San Quentin a century ago, measures can and must be taken to limit exposure to the disease. But the key ingredients of the pandemic - people with no immunity to the coronavirus in 
unavoidable daily contact - mean that the only proven protection is removing potential victims from the premises (Hawks et al., 2020). Officials could take the stand that health risks are inherent in incarceration and a collateral consequence of breaking the law. Since the onset of the pandemic in first quarter of 2020, however, elected and correctional leaders have not been so heartless as to suggest that illness and death from the coronavirus are simply a cost of crime. To varying degrees, they have taken steps release offenders to protect their health.

Efforts to cut jail populations have been most common, with many facilities achieving reductions of $25 \%$ or more (Widra and Wagner, 2020). According to the Prison Policy Initiative, the "largest known population reductions in local jails" have occurred in Clackamas, OR (66\%), Kitsap, WA (58\%), and Kenton, KY (52\%). Offenders are being released who otherwise would have been held for pretrial detention or been serving short sentences for nonviolent offenses. Officials also are stopping the flow of cases into jails by police not making arrests and by prosecutors not filing charges for low-level crimes (Widra and Wagner, 2020).

According to the Prison Policy Initiative, "most state prison systems show only very modest population reductions" (Widra and Wagner, 2020). Smaller states seem to have the largest decreases, with drops of 8-16\%. Larger states as well as the Federal Bureau of Prisons, have meaningful reductions, but these are in the range of $2-4 \%$ ("Reducing Jail and Prison Populations," 2020; Widra and Wagner, 2020).

As of May 5, 2020, the Federal Bureau of Prisons had 2066 inmates and 359 staff with the coronavirus; 41 of its charges had died ("Reducing Jail and Prison Populations," 2020). In response, the Bureau relied heavily on home confinement, placing 4700 offenders under this form of community supervision ("Reducing Jail and Prison Populations," 2020). Michael Cohen, President Trump's former personal lawyer, was one of these releasees (Associated Press, 2020). The challenge for state prisons, which incarcerate nearly 1.3 million offenders (Carson, 2020), is the composition of its population: $55.2 \%$ convicted for a violent offense and $14.8 \%$ for a drug offense. By contrast, the same figures for federal prisons are $7.9 \%$ for a violent offense and $48.3 \%$ for a drug offense ("Trends in U.S. Corrections," 2018). These statistics are significant because expanding prisoner releases in state prisons will meet the challenge of running out of so-called "low-level drug offenders" that ostensibly pose little threat to public safety. The tricky issue is how to release prisoners whose conviction offense does not make them appear "low risk," while also protecting the public from undue criminal victimization. One tool to aid in this decision making is the RNR model.

\section{Using the RNR Model to Release Prisoners}

The risk-need-responsivity (RNR) model is a theoretically and empirically informed approach to offender management. This model requires that trained practitioners use validated assessment instruments to identify the risks and needs of offenders. In this case, risk refers to level of supervision and services to be delivered to the offender as well as the offender's likelihood of recidivism. Accordingly, offenders who are identified as being high risk would be closely supervised and would receive the most treatment services. Conversely, offenders identified as low risk would receive the fewest treatment services and would require limited, if any, supervision. In addition to determining an offender's risk, the assessment instruments identify an offender's 
criminogenic needs - that is, factors that have been empirically shown to be associated with criminal activity (e.g., criminal history, education/employment, substance use, antisocial attitudes, antisocial associates, antisocial personality, leisure activities, and family/marital problems). The responsivity portion of the RNR model considers the risks and needs of the offender and then matches them to treatment services that are designed to target their criminogenic needs and reduce the offender's risk level (Andrews, Bonta, and Hoge, 1990; Andrews, Bonta, and Wormith, 2006; Andrews, Bonta, and Wormith, 2011).

The risk portion of the RNR model has historically been used to make decisions about where an offender is housed and the amount of treatment services needed (Andrews and Bonta, 1995). However, recent research has brought to light the importance of administering multiple risk/needs assessments (Cohen, Lowenkamp, and VanBenschoten, 2016; Labrecque, Smith, Lovins, and Latessa, 2014; Vose, 2016; Vose, Smith, and Cullen, 2013). The initial assessment provides valuable information about housing, amount and types of services needed. The follow-up assessments indicate the degree to which the treatment services are working to reduce the offender's risks/needs. A reduction in risks/needs may allow for an offender to be moved to a less restrictive housing unit and to receive reduced treatment services (Vose et al., 2013). Subsequent risk/needs assessments may also be used to identify individuals whose risk levels have decreased to the point where treatment can be discontinued and who are ready for release.

Two important considerations are relevant. First, risk level does not simply reflect the offense for which a prisoner was incarcerated. Criminal history is important, of course, but not fully determinative of a person's threat to public safety. Other risk factors also inform this assessment. Second, risk level is dynamic, not static. Incarcerated individuals' risk to society can change. The person who entered the prison years and even months ago may not have the same likelihood of reoffending today. This is why the use of multiple risk assessments is important. In fact, administering risk assessment now can provide updated, invaluable information on which prisoners fall into the pool of low-risk offenders.

In this context, the use of validated risk/needs assessment to identify candidates for targeted release is especially pertinent today as the country strives to slow the spread of COVID-19. Freeing space in overcrowded correctional institutions will enable facilities to implement social distancing measures, use enhanced cleaning protocols, and modify other institutional practices in a way that may limit the spread of COVID-19 to inmates and staff. Further, the removal of eligible candidates from institutions will provide much-needed space to safely quarantine those inmates who have already been infected. Finally, reducing the number of inmates in institutions will increase the likelihood that institutional medical personnel can adequately treat the health needs of the inmate population.

Of course, practical problems will have to be overcome. Undertaking assessments during the pandemic and with limited trained staff in any given facility poses obvious challenges. One option is to conduct a "virtual visit" where assessments are conducted via online technology by staff located centrally in the department of corrections or by outside consultants who have RNR model expertise and might live across the nation. Fortunately, the Level of Supervision Inventory-Revised (LSI-R) is intended to be user friendly, taking only about an hour to complete. The LSI-R is comprised of "54 risk 
and needs items, each scored in a zero-one format and distributed across 10 subcomponents (e.g., Criminal History, Education/Employment, Leisure)" (Andrews and Bonta, 2010, p. 316; see also Andrews and Bonta, 1995). In the end, offenders can be assigned into a risk level of low, medium, or high.

The challenge for policy-makers is where to draw the line in deciding who to return to society. Clearly, low-risk offenders are prime candidates for release, whereas highrisk offenders are not. Less clear is whether to release moderate-risk prisoners who could be "false negatives" if returned to the community on the assumption they would not recidivate. In this regard, the LSI-R is useful in identifying unmet criminogenic needs among such offenders (e.g., substance-abuse problem, anger management deficit). One option is to make the release of moderate-risk inmates contingent on placement in a treatment program that addresses unmet needs or to prioritize their receiving in-prison treatment prior to their return to the community.

In short, the use of targeted release is an evidence-based approach to offender management that will help corrections institutions operate more effectively and efficiently without unduly jeopardizing public safety. Specifically, the targeted release of offenders from an institutional setting will reduce operational costs and allow correctional staff to direct treatment services to those most in need. Additionally, the use of targeted release will help limit the transmission of COVID-19 to staff and inmates within correctional institutions. Finally, the use of targeted release aligns with the public's desire to reduce the size of the prison population (Sundt et al., 2015; Thielo et al., 2016).

\section{Conclusion}

The impact of the coronavirus pandemic is ongoing and far-reaching. The way in which COVID-19 spreads coupled with our reliance on correctional facilities as total institutions has further exacerbated the spread of the virus to correctional staff and the offender population. While federal and state governments ramp up testing and scientists search for a cure, correctional facilities and staff find themselves in uncharted territory and with few resources available. The use of validated offender risk/needs assessments to identify individuals eligible for targeted release is an evidence-based approach to offender management that will save lives during the coronavirus pandemic without sacrificing public safety.

Much will be involved in the rapid release and reentry of incarcerated individuals. For example, it might be necessary to test and quarantine these releasees either before or immediately after reentry. Planning will be essential to arrange for returning offenders temporary housing (possibly in unused motels rented by the state), appropriate medical services, and adequate financial support ("Recommendations for Rapid Release and Reentry," 2020). Still, for a policy of mass release to retain legitimacy, a concern for public safety must remain prominent among these other challenges. Already, reports are being publicized about released prisoners committing violent crimes, such as rape (Wallace, 2020). Although preventing such victimizations completely is unlikely, officials must be able to show that their decisions are informed by the best evidence possible. Use of the RNR model to assist in targeted release is an important resource in showing a genuine attempt to balance health and public safety interests in a time of national crisis. 
Finally, the tragedy of the pandemic might contain a silver lining for corrections. If the RNR model and other precautions can allow for the safe, premature reentry of tens of thousands of incarcerated individuals, this fact might well call into question the necessity of imprisoning these offenders in the first place. In an era in which faith in mass imprisonment already is waning, this natural experiment in mass release, if successful, might prompt a fundamental rethinking of sentencing policy. Further, as many Americans experience the pains of sheltering and a blocked future- the functional equivalence of incarceration - they may develop more empathy for what life behind bars entails (Fowers and Wan, 2020). It would be ironic but welcomed if the pandemic produced not only great hurt and loss but also a shared sense of humanity that extended to the nation's institutionalized populations.

\section{References}

Andrews, D. A., \& Bonta, J. (1995). LSI-R: The level of service inventory revised user's manual. North Tonawanda, NY: Multi-Health Systems.

Andrews, D. A., \& Bonta, J. (2010). The psychology of criminal conduct (5th ed.). New Providence, NJ: Anderson.

Andrews, D. A., Bonta, J., \& Hoge, R. D. (1990). Classification for effective rehabilitation: Rediscovering psychology: . Criminal Justice and Behavior, 17(1), 19-52.,

Andrews, D. A., Bonta, J., \& Wormith, J. S. (2006). The recent past and near future of risk and/or need assessment. Crime \& Delinquency, 52(1), 7-27.

Andrews, D. A., Bonta, J., \& Wormith, J. S. (2011). The risk-need-responsivity (RNR) model: Does adding the good lives model contribute to effective crime prevention? Criminal Justice and Behavior, 38(7), 735-755.

Associated Press. (2020, April 17). Ex-Trump lawyer Cohen being released from prison. MarketWatch. Retrieved from https://www.marketwatch.com/story/ex-trump-lawyer-cohen-being-released-from-prison2020-04-17

Brown, A. (2020, April 21). Insider Rikers: An account of the virus-stricken jail from a man who managed to get out. The Intercept. Retrieved from https://theintercept.com/2020/04/21/coronavirus-rikers-island-jail-nyc/

Bryant, M. (2020, April 1). Coronavirus spread at Rikers is a 'public health disaster', says jail's top doctor. In The Guardian Retrieved from https:/www.theguardian.com/us-news/2020/apr/01/rikers-island-jailcoronavirus-public-health-disaster.

Carson, E. A. (2020). Prisoners in 2018. Washington, DC: Bureau of Justice Statistics, U.S. Department of Justice.

Cohen, T. H., Lowenkamp, C. T., \& VanBenschoten, S. W. (2016). Does change in risk matter? Examining whether changes in offender risk characteristics influence recidivism outcomes. Criminology \& Public Policy, 15(2), 263-296.

Coronavirus in the U.S.: Latest Map and Case Count. (2020a, May). 4. New York Times. Retrieved from https://www.nytimes.com/interactive/2020/us/coronavirus-us-cases.html.

Coronavirus in the U.S.: Latest Map and Case Count. (2020b , May27). New York Times. Retrieved from https://www.nytimes.com/interactive/2020/us/coronavirus-us-cases.html

del Rio, C., \& Malani, P. N. (2020, April 14). COVID-19-New insights on a rapidly changing epidemic. JAMA, 323(14), 1339-1340.

Dickerson, C., \& Jordan, M. (2020, April). 15. New York Times: South Dakota meat plant is now country's biggest coronavirus hot spot Retrieved from https://www.nytimes.com/2020/04/15/us/coronavirus-southdakota-meat-plant-refugees.html.

Dyal, J. W., Grant, M. P., Broadwater, K., Bjork, A., Waltenburg, M. A., Gibbins, J. D., et al. (2020, May 1). COVID-19 among workers in meat and poultry processing facilities-19 states, April 2020. Morbidity and Mortality Weekly Report, 69(18), 557-561 Retrieved from https://www.cdc.gov/mmwr/volumes/69 /wr/pdfs/mm6918e3-H.pdf.

Enns, P. (2016). Incarceration nation: How the United States became the most punitive democracy in the world. New York, NY: Cambridge University Press. 
Faust, J. S., \& del Rio, C. (2020, May). 4. Washington Post: The metric that could tell us when its safe to reemerge Retrieved from https:/www.washingtonpost.com/opinions/2020/05/04/metric-that-could-tellus-when-its-safe-reemerge/.

Fowers, A., \& Wan, W. (2020, May 26). A third of Americans now show signs of clinical anxiety or depression. Washington Post: Census Bureau finds amid coronavirus pandemic Retrieved from https://www.washingtonpost.com/health/2020/05/26/americans-with-depression-anxietypandemic/?arc404=true.

Franklin, D., \& Reis, J. (2020, March). 24. Bully Pulpit Interactive: Majority of voters support releasing vulnerable people from prisons and jails in times of coronavirus Retrieved from https://www.aclu. org/other/aclu-and-bully-pulpit-interactive-poll-release-prisons-and-jails-amid-covid-19.

Goffman, E. (1961). Asylums: Essays on the social situation of mental patients and other inmates. Garden City, NY: Anchor Books.

Hammel, T. (2020, April 9). Charlottesville attorney files suit seeking release of certain prisoners amid COVID-19 pandemic. In The daily Progress Retrieved from https://www.dailyprogress. $\mathrm{com} / \mathrm{news} /$ local/charlottesville-attorney-files-suit-seeking-release-of-certain-prisoners-amid-covid-19pandemic/article_ba5098b0-5b14-5e73-ba57-a7b59285e84a.html.

Hawks, L., Woolhandler, S., \& McCormick, D. (2020). COVID-19 in prisons and jails in the United States. JAMA Internal Medicine. Advance online publication. https://doi.org/10.1001/jamainternmed.2020.1856.

Healy, J., \& Kovaleski, S. F. (2020, March). 21. New York Times: The coronavirus's rampage through a suburban nursing home Retrieved from https://www.nytimes.com/2020/03/21/us/coronavirus-nursinghome-kirkland-life-care.html.

Labrecque, R., Smith, P., Lovins, B., \& Latessa, E. J. (2014). The importance of reassessment: How changes in the LSI-R risk score can improve the prediction of recidivism. Journal of Offender Rehabilitation, 53(2), 116-126.

Levenson, E., Holcombe, M., Azad, A., \& Almasy, S. (2020, May 4). Coronavirus model projects 134,000 deaths in US, nearly double its last estimate. CNN. Retrieved from https://www.cnn.com/2020/05/04 /health/us-coronavirus-monday/index.html

Mallapaty, S. (2020, April 2). What the cruise-ship outbreaks reveal about COVID-19: Closed environments are an ideal place to study how the new coronavirus behaves. Nature, 80(580), 18.

Matz, J. (2020, April). 20. The Atlantic: The coronavirus is testing America's commitment to people's constitutional rights Retrieved from https:/www.theatlantic.com/ideas/archive/2020/04/coronavirusjails-constitutional-rights/610216/.

Moriarty, L. F., Plucinski, M. M., Marston, B. J., Kurbatova, E. V., Barbara Knust, B., Murray, E. L., ... Solano County COVID-19 Team. (2020, March 27). Public health response to COVID-19 outbreaks on cruise ships-Worldwide, February-march 2020. Morbidity and Mortality Weekly Report, 69(12), 347352.

Nadolny, T. L., \& Kwiatkowski, M. (2020, May 3). 16,000 dead in US nursing homes (p. 6B). Cincinnati Enquirer.

Pickett, J. T. (2019). Public opinion and criminal justice policy: Theory and research. Annual Review of Criminology, 2, 405-428.

Potter, R. H., \& Rosky, J. W. (2014). The healthy prison. In F. T. Cullen, C. L. Jonson, \& M. K. Stohr (Eds.), The American prison: Imagining a different future (pp. 151-170). Thousand Oaks, CA: Sage.

Recommendations for Rapid Release and Reentry During the COVID-19 Pandemic. (2020). NYU Marion Institute of Urban Management. Retrieved from https://marroninstitute.nyu.edu/papers/recommendationsfor-rapid-release-and-reentry-during-the-covid-19-pandemic

Reducing Jail and Prison Populations During the Covid-19 Pandemic. (2020, May 5). Brennan Center for Justice. Retrieved from https://www.brennancenter.org/our-work/research-reports/reducing-jail-andprison-populations-during-covid-19-pandemic

Samilton, T. (2020, April 30). Lawsuit alleges "cruel and unusual punishment" in state prisons during pandemic. In Michigan radio Retrieved from https://www.michiganradio.org/post/lawsuit-alleges-crueland-unusual-punishment-state-prisons-during-pandemic.

Seligman, L. (2020, May 4). USS Theodore Roosevelt sailors still showing virus symptoms despite month of isolation. Politico. Retrieved from https://www.politico.com/news/2020/05/04/navy-sailors-coronavirususs-roosevelt-234125

Sheikh, K., Watkins, D., Wu, J., \& Gröndahl. (2020, February 28). How bad with the coronavirus outbreak get? Here are 6 key factors. New York Times. Retrieved from https://www.nytimes.com/interactive/2020 /world/asia/china-coronavirus-contain.html.

Stanley, L. L. (1919). Influenza at san Quentin prison, California. Public Health Reports, 34(19), 996-1008. 
Sundt, J., Cullen, F. T., Thielo, A. J., \& Jonson, C. L. (2015). Public willingness to downsize prisons: Implications from Oregon. Victims \& Offenders, 10(4), 365-378.

Tennessean Staff. (2020, May 2). Coronavirus in Tennessee prisons: Key questions surrounding the outbreak. Tennessean. Retrieved from https://www.tennessean.com/story/news/health/2020/05/02/coronavirusoutbreak-prisons-jails-tennessee/3072094001/

Thielo, A. J., Cullen, F. T., Cohen, D. M., \& Chouhy, C. (2016). Rehabilitation in a red state: Public support for correctional reform in Texas. Criminology \& Public Policy, 15(1), 137-170.

Thompson, S. A. (2020, May 3). How long will a vaccine really take? New York Times, p. SR5.

Toussaint, K. (2020, March 12). Prisons are going to be an incredibly dangerous place in a pandemic. Fast Company. Retrieved from astcompany.com/90476167/prisons-are-going-to-be-an-incredibly-dangerousplace-in-a-pandemic.

Trends in U.S. Corrections. (2018, June 22). The Sentencing Project. Retrieved from https://www. sentencingproject.org/wp-content/uploads/2016/01/Trends-in-US-Corrections.pdf

Volpenhein, S. (2020a, April). 25. Marion Star: Marion prison coronavirus outbreak seeping into larger community Retrieved from https://www.marionstar.com/story/news/local/2020/04/25/marion-prisonohio-coronavirus-outbreak-seeping-into-larger-community/3026133001/.

Volpenhein, S. (2020b, April). 25. Marion Star: Ohioans protest treatment of Marion prisoners left exposed to coronavirus Retrieved from https:/www.marionstar.com/story/news/local/2020/04/26/ohioans-protesttreatment-marion-prisoners-exposed-coronavirus/3027722001/.

Vose, B. (2016). Risk assessment and reassessment: An evidence-based approach to offender management. Criminology \& Public Policy, 15(2), 301-308.

Vose, B., Smith, P., \& Cullen, F. T. (2013). Predictive validity and the impact of change in total LSI-R score on recidivism. Criminal Justice and Behavior, 40(12), 1383-1396.

Wallace, D. (2020, April 26). NYC man released from Rikers Island over coronavirus arrested on new rape charge: Report. In Fox news Retrieved from https://www.foxnews.com/us/new-york-brooklyn-inmaterikers-island-rape-arrest-coronavirus.

Webeck, E. (2020, April 6). Coronavirus: After weeks of quarantine and 3 dead. Mercury News: Grand Princess sets sail again Retrieved from https:/www.mercurynews.com/2020/04/06/coronavirus-afterweeks-of-quarantine-and-3-dead-grand-princess-sets-sail-again/.

Widra, E., \& Wagner, P. (2020, May 1). While jails drastically cut populations, state prisons have released almost no one. In Prison policy initiative Retrieved from https://www.prisonpolicy.org/blog/2020/05/01 /jails-vs-prisons/.

Wilson, R. (2020, May 1). Brutal April ends with US facing difficult May. The Hill. Retrieved from https://thehill.com/homenews/state-watch/495710-brutal-april-ends-with-us-facing-difficult-may

Publisher's Note Springer Nature remains neutral with regard to jurisdictional claims in published maps and institutional affiliations.

Brenda A. Vose, Associate Professor, is Chair of the Department of Criminology and Criminal Justice at the University of North Florida. Her research interests include offender assessment and classification, effective treatment interventions, and community corrections. Her articles have appeared in Criminal Justice and Behavior, Federal Probation, and Victims \& Offenders.

Francis T. Cullen is a Distinguished Research Professor Emeritus and Senior Research Associate at the University of Cincinnati. He is a past president of the American Society of Criminology and the Academy of Criminal Justice Sciences. His current research interests focus on redemption as a correctional theory, racial beliefs and public policy, and the criminology of Donald Trump.

Heejin Lee is a doctoral candidate in criminal justice at the University of Cincinnati. Her main interests include the impact of narrative identities on offender desistance, perceptual deterrence, criminological theory, and the relationship of generational membership to support for progressive correctional policies. Her work has appeared in Justice Quarterly, Criminal Justice and Behavior, and Advances in Criminological Theory. 